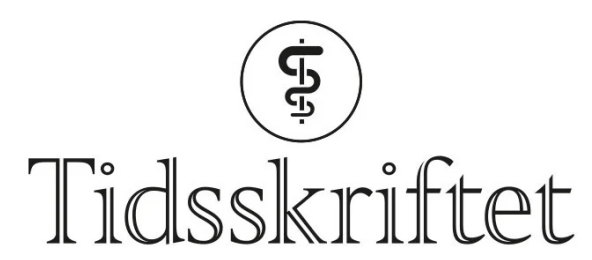

DEN NORSKE LEGEFORENING

\title{
Blogging om mobbing
}

ANMELDELSER

GUNILLA KLENSMEDEN FOSSE

DPS Nidaros

St. Olavs hospital

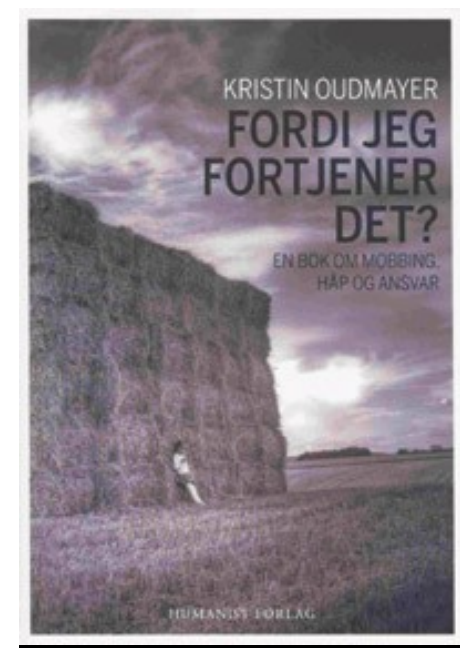

Oudmayer, K.

Fordi jeg fortjener det?

En bok om mobbing, håp og ansvar. 245 s, ill. Oslo: Humanist forlag, 2010. Pris NOK 299

ISBN 978-82-92622-61-2

På tross av flere års søkelys på å forebygge mobbing er det fortsatt vanlig. Hvorfor er det slik? Det er forfatterens utgangspunkt. Boken består av 4o historier om mobbing. Historiene er samlet inn av forfatteren ved hjelp av sosiale medier. De fleste historiene er basert på selvopplevde hendelser. Ved å gi vanlige folk en stemme - en stemme som vanligvis ikke høres - ønsker forfatteren å få mer innsikt i problematikken, samtidig som debatten får større bredde.

De fleste historiene handler om typiske mobbesituasjoner i skolen, for eksempel om barnet som forventningsfullt begynner i første klasse, for deretter å oppleve mange år med fornedring. De fleste fortellerne er kvinner, ofte flinke jenter som har fått høre at de «tåler» å bli mobbet. Mennenes historier er mer preget av å ta igjen. Iblant har de mistet 
kontrollen, hvilket i seg selv er skremmende. Felles for de fleste historiene er mangelen på innsikt og tiltak fra skolens side, men det finnes unntak: En skole har absolutt nulltoleranse for mobbing. Ved en annen skole inviterer den nye læreren mobberen og offeret hjem til seg og spør mobberen hva han ikke liker hos offeret. Svaret er befriende: Mobberen vet ikke, og deretter er et flerårig mobbehelvete over. Så enkelt!

Andre historier handler om mobbing fra familiemedlemmer, i arbeidslivet eller pga. religiøs tro. Symptomene er i hovedsak de samme: kvalme, angst, depresjon, selvmordstanker og av og til selvmordsfors $ø$ k. Selvskading er også vanlig, i likhet med mareritt, flashbacks, usikker identitetsfølelse og i etterkant skvettenhet i kontakt med situasjoner som minner om tidligere mobbesituasjoner. Flere skriver at de har kommet styrket ut av det, men mange har trengt psykiatrisk behandling.

Boken gir ikke svar på hvordan man forebygger mobbing, men flere mener at politikerne har et ansvar. I den siste historien, fortalt av kunnskapsministeren, skriver hun at vi må gjøre det og det. Det er en bra innstilling, men her kreves konkrete handlinger; ca. halvparten av pasientene ved en psykiatrisk voksenpoliklinikk rapporterer om mobbing i skolen. I tillegg kommer alle de som rapporterer om mobbing i familier, på arbeidsplasser og i foreninger. Her er det bare forebygging som på sikt kan hjelpe. I mellomtiden får vi fortsette å behandle ofrene.

Til sist, til forfatteren: Hva med å få mobberne i tale? Eller de som så på, men ikke gjorde noe? Kanskje har de informasjon som vi trenger for å løse «mobbegåten»?

Publisert: 17. juni 2010. Tidsskr Nor Legeforen. DOI: 10.4045/tidsskr.10.0435

(C) Tidsskrift for Den norske legeforening 2023. Lastet ned fra tidsskriftet.no 26. april 2023. 